\title{
The Effect of Perceived Benefits Technology User, The Perception of Technology User Convenience, and the Price of Transportation to the Interests of Users Get Online Application
}

\author{
Zulfitri \\ Departement of Management Faculty of Economics and Business, Universitas Mercu Buana
}

\begin{abstract}
This study aims to determine the effect of the perception of the benefits of technology, perceived ease of technology, and transportation prices online against user interests transportation applications online. This research is the consumer in transportation applications users online. This study uses the 100 respondents, the sampling technique used is the convenience sampling technique as a technique of determining the sample. The analysis is Partail Least Square. These results indicate that the perception of the benefits of a significant effect on transport applications online user interest, perceived ease is not positive and significant effect on the interests of users, and the price of significant positive effect on user interest transportation applications online.
\end{abstract}

Keywords: Perceived benefits, Perceived Ease, and prices on the online transport User Interest

DOI: $10.7176 / \mathrm{EJBM} / 11-35-12$

Publication date: December $31^{\text {st }} 2019$

\section{Introduction}

The phenomenon of transportation growth increasingly advanced, formerly conventional transport such as public transport such as taxis, buses, public transportation, tricycle, motorcycle, and others we get stops, terminals or at the base, the other thing with the taxi that progress had been made, with how to order over the phone the taxi in the message will come at the passenger pick-up location, and payment systems is also done when passengers arrive at the destination with cash payment / cash. But with advances in technology, one can utilize these technologies to increase profits, while increasing profits also make it easier to use. As we look towards developing transport online today at Gojek, Grab, Uber. Transport line was first established in Indonesia in 2011 which begins by Gojek and founded by Nadiem Makarim, then officially launched Go-Jek application in early 2015.Gojek is a socially minded company that leads the transport industry revolution Ojeks,

Currently the development of internet happens very quickly and can reach the whole world and every business person wants their products are widely recognized by the public, especially Indonesia, data from a survey conducted by a global institution Indonesian index ranks seventh largest in the world in Internet usage.

APJII and PusKaKom research results illustrate that the surge of Internet users in Indonesia which would significantly impact to the industrial development of the economy. The Internet offers opportunities for product sales of daily necessities of life directly to customers who are in the consumer market (consumer market) or consumers in the industrial market (business-to-business market).

Transport is very important for today's society, which is to facilitate the activities of those who want easy transportation, fast, and secure. This time transport not only wear the conventional system that is just waiting in the street or waiting at the terminal, passengers now or users of public transport they want the convenience of ordering or using such transport can be accessed through the internet, and could always come to where they want without should go to the highway, the base or to the terminal.

The purpose of this study was to know the effect of the technological benefits Perception, Ease of technology, the price of transport to the interests of transportation users online in Jakarta.

\section{Literature review}

\subsection{Perception}

Robbins (2008) promoted that perception is the process by which individuals organize and menginter pretasikan their sensory impressions in order to give meaning to their environment.

Herlan and Yono (2013) in Noveline (2014) perception is a process by means of what someone is doing the selection, receiving, organizing, and interpreting the information it receives from the environment.

Moskowitz and ogel (in Walgito, 2003: 54) the perception is that the integrated process of the individual to the stimuli it receives. Thus it can be argued that this perception is the process of organizing, with the interpretation of the stimulus received by the organism or individual that is something that is meaningful and is an integrated activity within the individual.

\subsection{Perceived Benefit}

Adams, Nelson, \& Todd, 1992: 13) defines the perception of usefulness is a level of trust someone to use a 
particular subject to provide benefits for people who use them.

\subsection{Perceived Ease}

Davis (Winayu, 2013: 32) perceived ease of use is a level or a state in which a person believes that using a particular system is not required any effort.

Jogiyanto (2007: 115), perceived ease of use is defined the extent to which a person believe that the use of a technology system would be free of effort. From both of these definitions can be concluded that the perceived ease of use is a person's belief in using a technology system without requiring any effort or freedom from effort.

Brown (Winayu, 2013: 33) argues that the technology that has commands that are easy to find and easy to understand will affect a person's perception that the technology is easy to use.

\subsection{Interests To Use}

Interest for use can be defined as a form of user wishes to use or reuse a particular object. Interest is one aspect of the human psyche that tends to give attention or feel happy greater to the object that can be pushed to an end (Kusuma, 2009).

Intention is defined as the power of conscious behavior to do something that has been targeted (Keil, Beranek, and Konsynski, 1995). Intention is influenced by two basic factors, namely personal factors and factors of social influence. Both of these factors positively affects individual behavior intention to positively cause a behavior. Behavior is the actual actions of individuals as a result of the factors that influence it (Ajzen, 1991)

\subsection{Price}

Kotler and Keller (2009: 67) explains that "the price is one of the elements of the marketing mix that produces revenue, other elements produce costs". Medium Tjiptono (2008) explains that the price is one of the important variables in the market, where prices can influence consumers in making a decision to buy a product, for various reasons. Swastha (2010: 147) explains that "the price is the amount of money (plus a few items that may be) required to obtain a number of combinations of items and their ministry".

Referring to Kertajaya (2006) in Cahya (2015) indicator of price can be expressed in consumers' assessment of the amount of financial sacrifice given in relation to the specifications in the form of quality products. Besides the valuation price can be seen from the correspondence between the sacrifice of the consumer on the value of the receipt after making a purchase, and from which consumers will perceive the product or service. A positive perception is the result of a sense of satisfaction will be a purchase that is done, while the negative perception is a form of consumer dissatisfaction on the product or service. A positive perception is the result of a sense of satisfaction will be a purchase that is done, while the negative perception is a form of consumer dissatisfaction on the product or service purchased.

\subsection{Conceptual Framework and Hypothesis Development}

Perception benefit is defined as the perception of the benefits is a degree to which a person believes that using a particular system would be able to increase the person's job performance (Davis, 1989). Perception of the benefits of a degree to which a person believes that using a particular system would be able to improve performance, increase productivity and effectiveness of work of the person (Koeswoyo, 2006). Perception of usefulness as a subjective probability of potential users who use a particular application to facilitate the performance on the job. Rahmatsyah (2011).

\section{Hypothesis 1: Perceived benefits of positive effect on the interest of users of transport services online} applications.

Jogiyanto (2009) states perceived ease of use is defined as the extent to which a person believes that using a technology would be free of effort. By definition it can be seen that the perception of convenience is an assertion about the decision-making process.

Perceived ease of use as a level where a person believes that using a particular system would be free of effort Davis (1989).

The technology that has commands that are easy to find and easy to understand will affect a person's perception that the technology is easy to use. Brown (Winayu, 2013: 33).

Hypothesis 2: Perceived ease positive effect on the interest of users of transport services online.

Kotler and Keller (2009: 67) explains that the price is one of the elements of the marketing mix that produces revenue, other elements generating costs.

Tjiptono (2008) explains that the price is one of the important variables in the market, where prices can influence consumers in making a decision to buy a product, for various reasons.

Swastha (2010: 147), the price is the amount of money (plus a few items that may be) required to obtain a number of combinations of items and their ministry.

Hypothesis 3: Prices positive effect on the interest of users of transport services online applications. 


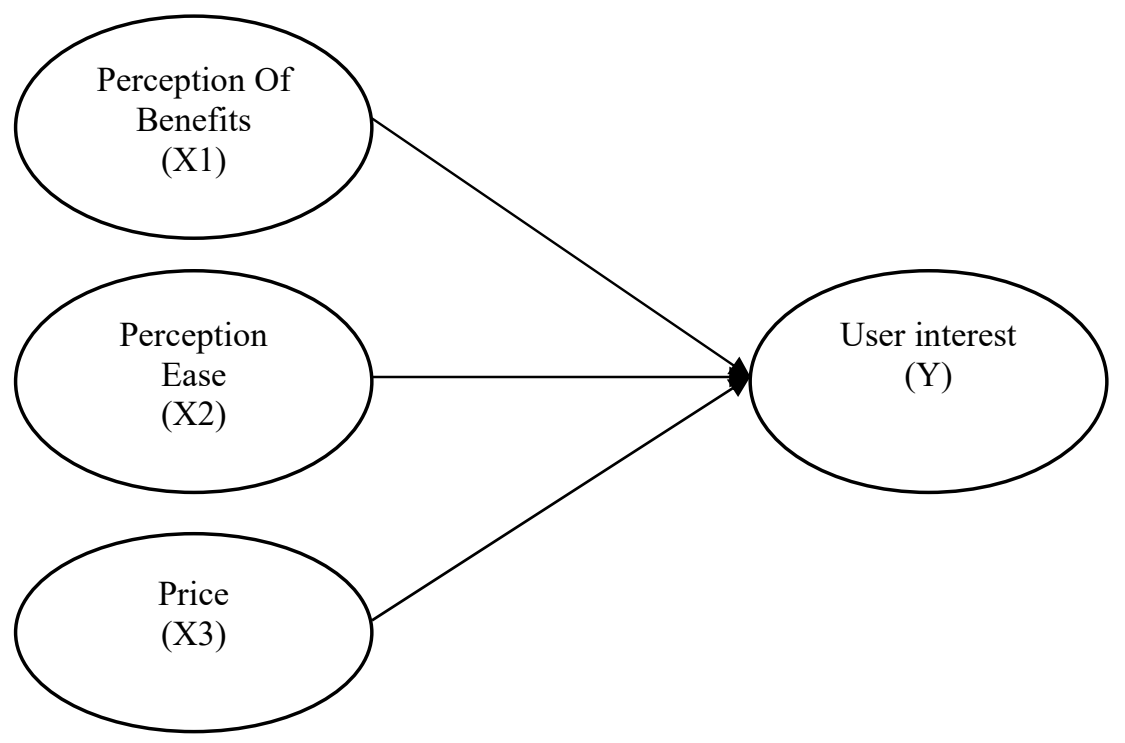

Figure 1 Framework

\section{Methodology}

\subsection{Population and Sample}

The population is a mix of all elements in the form of events, things or people who have similar characteristics that became the center of attention of the researchers because it is seen as a research universe, Ferdinand (2014). The population in this study are employees who have a Smartphone at Chase Plaza Tower Building 3rd and 4th floor, street Jend.Sudirman kav.21, South Jakarta.

The sample in this study were employees of smartphone users in Jakarta. The sample is part of the number and characteristics possessed by this population. When a large population, and researchers may learn all there is in the population, for example, because of limited funds, manpower, and time, researchers can use the sample drawn from that population. The greater the number of samples closer to the population, then the chances are getting smaller and vice versa generalization vanishingly small number of samples away from the population, the greater the generalization error (Sugiyono 2008).

From various sources (Ferdinand, 2006) obtained some sample guidelines that can be used in determining the size of the sample. Determination of the number of samples for a number of unknown population. The amount of sample required is known by 100 respondents.

\subsection{Measurement Scale}

The measurement method in this study using a Likert scale. Likert scale use more than one question, then the question it is useful to measure attitudes, opinions and perceptions, both positive and negative individuals or groups of symptoms that occur and can be observed in social life, or so-called social phenomena

\section{Analysis}

\subsection{Characteristics of Respondents}

that of 100 respondents are 8 or $8 \%$ of respondents aged between $15-20$ years, 33 respondents or $33 \%$ aged between $21-25$ years, 36 respondents or $36 \%$ are aged between $26-30,17$ respondents $17 \%$ were aged $31-35$ years, 4 people or $4 \%$ of respondents aged $36-40$ years, while remaining as much as 2 or $2 \%$ of respondents over the age of 41 years

that of 100 respondents consisted job characteristics of learners / students as much as 11 respondents, housewives by 2 respondents, private sector employees by 84 respondents, employees of State / BUMN 0 respondents, Self as much as 3

that of 100 respondents who have a monthly income of $<3,000,000$ as many as 9 respondents, 33000018000000 as many as 66 respondents, $8000001-15000000$ as many as 23 respondents, $>15,100,001$ as much as 2 respondents. It can be seen that the majority of respondents based on income is as much as 66 respondents $3300001-8000000$.

that of 100 respondents access the internet $\leq 1$ hours a day to as much as 2 respondents, $1-2$ hours a day as much as 9 respondents, 1-3 hours a day as many as 18 respondents, $1-4$ hours a day by 20 respondents, $>4$ hours a day in 49 respondents and the remaining 2 respondents.

that of 100 respondents who use such gadgets as much as 9 respondents Desktop, Laptop many as five respondents, as many as 4 respondents Tablet, Smartphone as many as 82 respondents. The majority of 
respondents who frequently use the gadget is a smartphone as much as 82 respondents.

\section{Result}

\section{Measurement Evaluation Model}

Outer design of the model by using software SmartPLS 3.0 can be seen in Figure below:

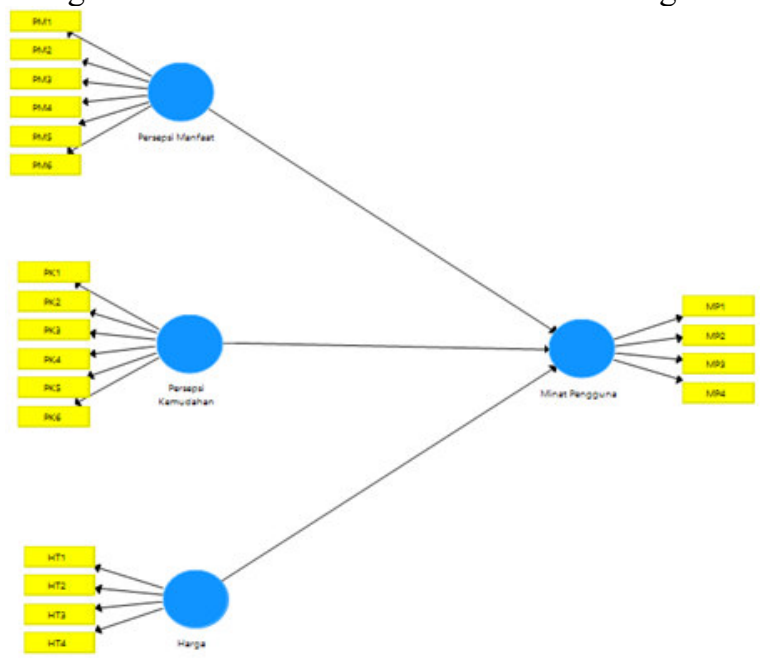

Figure 2 Design of the outer models

Source: The results of the questionnaire data processing

Convergent Validity



Figure 3 Output diagram the initial path

In figure 3 the path diagram above can be seen each indicator has a loading factor above 0.5 . Therefore, ideally the value loading factor above 0.7 , but 0.5 to 0.6 is still permitted, in this study loading factor below 0.6 should still be removed from the model due to their loading factor $<0.6$ in the variable PK that PK2 of 0523 the value of AVE variable PKM still below 0.5 , 


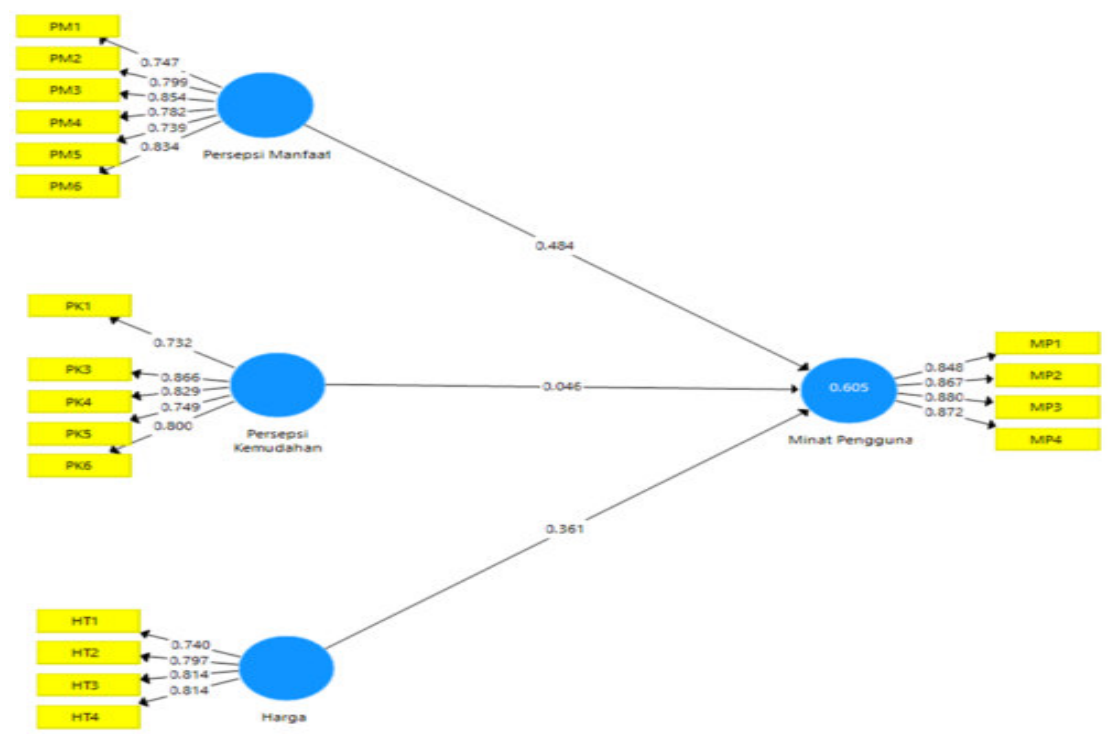

Figure 4 The results of the re estimation of outer loading

In the picture above can be seen the amount of re-loading factor estimation results indicate that all the indicators have had a good validity because it has a loading factor of more than 0.6. More detailed results of the outer loading estimation can be seen in the table below:

In table 1 above can be seen the value of AVE already indicated that all constructs had a reliability of potential for further testing. This is because the value of AVE on the whole construct has been greater than 0.5 . Discriminant Validity

Table 1 Resukt of Discriminant Validity

\begin{tabular}{ccccc}
\hline Indicator & loadings & AVE & Composite & CA \\
\hline PM1 & 0,747 & 0630 & 0911 & 0882 \\
PM2 & 0.799 & & & \\
PM3 & 0.854 & & & \\
PM4 & 0,782 & & & \\
PM5 & 0.739 & & 0896 & 0857 \\
PM6 & .834 & & & \\
PK1 & 0.732 & 0635 & & \\
PK3 & 0.866 & & & \\
PK4 & 0,829 & & & \\
PK5 & .749 & & & \\
PK6 & 0,800 & & & \\
HT1 & .740 & 0627 & & \\
HT2 & 0.797 & & & \\
HT3 & .814 & & & \\
HT4 & .814 & & & \\
MP1 & 0,848 & 0751 & & \\
MP2 & 0.867 & & & \\
MP3 & 0,880 & & & \\
MP4 & 0.872 & & & \\
\hline
\end{tabular}

Table 2 Endogenous Variable $R^{2}$ Value

\begin{tabular}{|l|l|}
\hline Endogenous variables & $\mathbf{R}$ - Square \\
\hline interests of Use & 0605 \\
\hline
\end{tabular}

Structural model indicates that the model of latent variables independent (Perceived Benefits, Perceived Ease and price of the Interests of Use give R - Square of 0605 that can be interpreted that the variable constructs Interests Usage explained by the construct of Perceived benefits, Perceived Ease and Price 60.5\% and 39.5\% explained by other variables outside the research. 


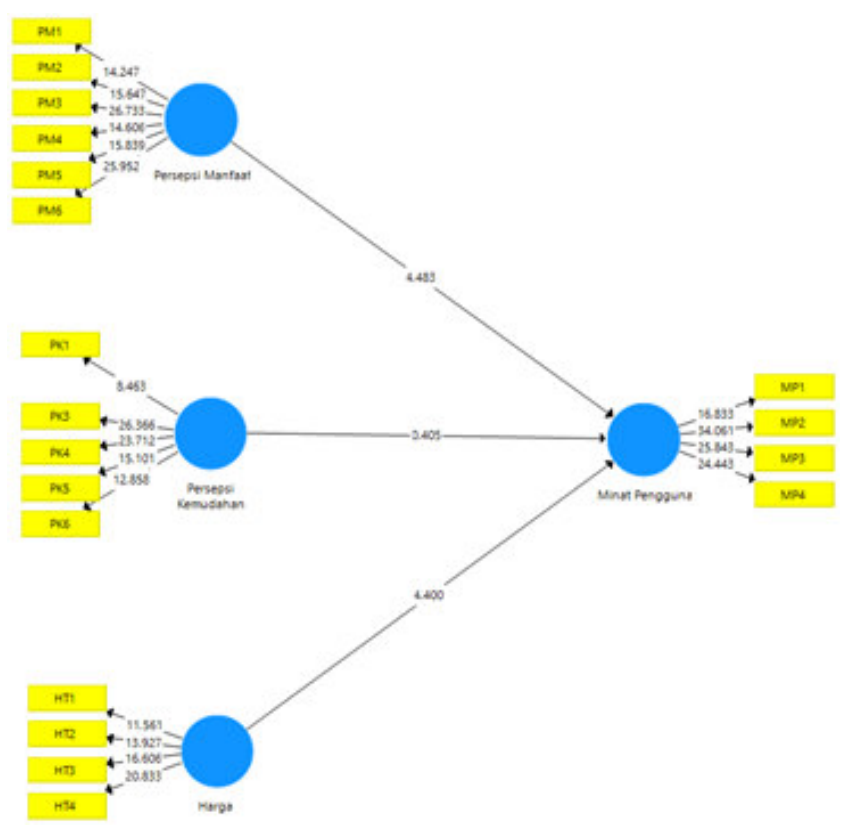

Figure 5 Test Results bootstrapping

Based on the above figure shows the results that the perception of significant benefits to interest in the use, it can be seen from the $\mathrm{T}$ - calculated at 4483 is greater than the $\mathrm{T}$ - table is 1.96 with an error tinggkat 0:05 (5\%). The original value estimate is a positive sample that is equal to 0484 which indicates that the direction of the relationship between the perception of the benefits of the use of interest. As for the variables perceived ease of no effect is not significant to the desirability of using, as shown by the value of $\mathrm{T}$ - count of 0405 is greater than $\mathrm{T}$ - Table 1.96 with an error rate of 0:05 (5\%). The original value estimate is a positive sample that is equal to 0046 which indicates that the direction of the relationship between perceived ease of use is the positive interest. Similarly, the price of positive and significant impact on the desirability of using, as shown by the value of $\mathrm{T}$ count of 4,400 is greater than $\mathrm{T}$ - Table 1.96 with an error rate of 0:05 (5\%). The original value estimate sample was positive in the amount of 0.361 which indicates that the direction of the relationship between perception of security against the interest of the use is positive. Hypothesis testing against the research model is as follows:

Variables affecting the perception of the proven benefits of transport applications online user interest significantly as has the $\mathrm{T}$ - Statisic above 1.96 is equal to 4,483 with the value of the original sample positive estimate for 0484 . Hypothesis 1 is accepted in this case where the influence of the perception of significant benefits to interest in the use of online transportation applications. Variable does not affect the perceived ease proven interest in the use of online transportation applications because it has a T - Statistic under 1.96 is equal to 0405 with the value of the original sample positive estimate for 0046 . Hypothesis 2 in this case is rejected where the influence of the perceived ease of not significant interest in the use of online transportation applications.Variable interest rates affect the use of proven online transportation applications significantly as has the $\mathrm{T}$ - Statistic above 1.96 is equal to 4,400 with the value of the original sample positive estimate of 0.361 . Hypothesis 3 in this case are accepted wherever significant influence on the interest rates of use transportation applications online.

\section{Discussion and Implications}

Under the first hypothesis testing known that the proposed H1 accepted or rejected. Thus the hypothesis H1 in this study stated that the perception of the benefits having a significant impact on the desirability of using transportation applications online.

The results of this hypothesis is consistent with studies previously conducted by Rahayu (2015) which showed that the perception of the benefits (perceived usefulness) has a positive effect on the behavior of interest in using mobile banking and some other research Pareno et al (2016); Lieu (2015); Dewi et al (2017); Dewi \& Warmika (2016); Wibowo et al (2015); Andriyano \& Rahmawati (2016) who get the same result, namely the perception of the benefits of having a significant impact on the desirability of using.

This study line with research conducted Gunawan (2014) with the title Application Technology Acceptance Model In Interests Using that get results that the perceived usefulness has no direct influence on the interest, but the indirect effect through attitude and research Wong (2016), which shows the results that perceived ease of use had little effect on behavioral intention of use.

Based on the hypothesis explained that $\mathrm{H} 2$ denied. Thus the hypothesis $\mathrm{H} 2$ in this study stated that the perceived ease of not having a significant impact on transport applications online user interest. 
The results of this hypothesis is not consistent with research conducted by Kumar et al (2017) who get the results that the perceived ease of use an underlying factor or influence the behavioral intention to useand several other researchers such as Rahayu (2015); Lieu et al (2015); Dewi et al (2017); Dewi \& Warmika (2016); Wibowo et al (2015); Andriyano \& Rahmawati (2016), which also showed that perceived ease of use affect the interests of use. This study is in line with Wong (2016), Pareno et al (2016), and Gunawan (2014) .The perceived ease of getting results indirectly affect the interests of small and use.

Based on the hypothesis outlined that H3 proposed accepted. Thus the hypothesis H3 in this study stated that the price of transport has a significant effect on the interest in the use of online transportation applications. According to Kotler and Keller (2009: 67) the price is one of the elements of the marketing mix that produces revenue, other elements generating costs.

This is consistent with the results of research conducted by Handy (2013) which showed that prices had a significant impact on users' interests. Results of research conducted Reinhard, (2014) showed that the price effect on user interest transportation applications online.

Thus it can be said that the hypothesis $\mathrm{H} 1$ and $\mathrm{H} 3$ in this study received. $\mathrm{T}$ - statistically significant because under the $\mathrm{H} 2$ tdak $\mathrm{T}$ - table 1.96 indicating that the hypothesis $\mathrm{H} 2$ is rejected.

\section{Limitations and Future Research}

Providers of online transportation applications can be developed further product service features, ease of use so that consumers can better understand the benefits and ease of use of online transportation applications. And the price set by the provider of online applications by author has been quite influential in consumers choose to use the online transport applications in comparison with transport konvidensial, but better-more application providers often provide discounts or price discounts in order to future improve the consumer in using transportation applications online.

The results of this study can be used as a reference for further research would like to continue this research, it is advisable to extend the model and add other variables related, in order to explain more about other factors that affect the perception of the benefits of the technology, perceived ease of use of technology and price transportation on transport applications online user interest.

\section{Reference}

Agusli, D. (2013). Analisa pengaruh dimensi ekuitas merek terhadap minat beli konsumen Midtown Hotel Surabaya. Jurnal Strategi Pemasaran, 1(2), 1-8.

Binalay, A. G., Mandey, S. L., \& Mintardjo, C. M. (2016). Pengaruh Sikap, Norma Subjektif Dan Motivasi Terhadap Minat Beli Secara Online Pada Mahasiswa Fakultas Ekonomi Dan Bisnis Di Manado. Jurnal EMBA: Jurnal Riset Ekonomi, Manajemen, Bisnis dan Akuntansi, 4(1).

Cahya, E, (2015). Pengaruh Kualitas Produk dan Harga Terhadap Keputusan Pembelian Smartphone Sony Experia Z Series Di Counter Insight Plaza Marina Surabaya Program Study S1 Pendidikan Ekonomi. Skripsi tidak diterbitkan. Surabaya. PPs Universitas Negeri Surabaya.

Castells, M, (2004). The Network Society, A Cross-cultural Perspective.Massachusets: Edward Elgar Publishing Inc.

Cao, T. K., Dang, P. L., \& Nguyen, H. A. (2016). Predicting consumer intention to use mobile payment services: Empirical evidence from Vietnam. International Journal of Marketing Studies, 8(1), 117.

Fure, H. (2013). Lokasi, keberagaman produk, harga, dan kualitas pelayanan pengaruhnya terhadap minat beli pada pasar tradisional Bersehati Calaca. Jurnal Emba: Jurnal Riset Ekonomi, Manajemen, Bisnis dan Akuntansi, 1(3).

Ferdinand, A. (2014). Metode Penelitian Manajemen: Pedoman Penelitian untuk Penulisan Skripsi Tesis dan Disertai Ilmu Manajemen. Semarang: Penerbit Universitas Diponegoro.

Ghoni \& Bodroastuti, (2012). Pengaruh Faktor Budaya, Sosial, Pribadi Dan Psikologi Terhadap Perilaku Konsumen (Studi Pada Pembelian Rumah di Perumahan Griya Utama Banjardowo Semarang). Jurnal Kajian Akuntansi dan Bisnis, 1(1).

Ghozali, I. \& Latan, H. (2015). Partial Least Squares (Konsep, Teknik dan Aplikasi Menggunakan Program SmartPLS 3.0). Semarang: Badan Penerbit Universitas.

Jogiyanto. (2007). Sistem Informasi Keperilakuan. Yogyakarta: Andi.

Kodu, S. (2013). Harga, Kualitas Produk Dan Kualitas Pelayanan Pengaruhnya Terhadap Keputusan Pembelian Mobil Toyota Avanza. Jurnal EMBA: Jurnal Riset Ekonomi, Manajemen, Bisnis dan Akuntansi, 1(3).

Kotler, P.(2012). Principles of Marketing. New Jersey: Pearson Education Limited.

Kim, M. S., \& James, J. (2016). The theory of planned behaviour and intention of Purchase sport team licensed merchandise. Sport, Business and Management: An International Journal, 6(2), 228-243.

Lamb, Charles. W. et.al. 2001. Pemasaran. Buku I Edisi Pertama. Penerbit Salemba Empat. Jakarta.

Machfoed. M.(2005). Perilaku konsumen.jilid 1.penerbit akademi manajemen 
Muflihhadi, I., \& Rubiyanti, R. N. (2016). Pengaruh Perceived Usefulness, Perceived Ease Of Use, Dan Trust Terhadap Kepuasan Konsumen (studi Pada Gojek Bandung). E Proceedings of Management, 3(2). perusahaan.yogyakarta.

Mulyani, S. (2017). Pengaruh Kemampuan Tehnologi Informasi, Kemudahan, Risiko Dan Fitur Layanan Terhadap Minat Nasabah Dalam Menggunakan Internet Banking (Studi Empiris Pada Nasabah Bank Rakyat Indonesia Di Kota Banjarmasin). Dinamika Ekonomi-Jurnal Ekonomi dan Bisnis, 10(1).

Noor, J. 2014. Metodologi Penelitian. Kencana. Jakarta

Martono, N. 2012. "Sosiologi Perubahan Sosial: Perspektif Klasik, Modern, Postmodern, dan Postkolonial”. Jakarta:PT. Raja Grafindo Persada.

Salim, A. (2000). Edisi kedua. Manajemen Transportasi. Jakarta: Ghalia Indonesia.

Swastha dan Irawan. (2010). “Manajemen Pemasaran Modern” Liberty, Yogyakarta.

Sugiyono, (2008). Metode Penelitian Bisnis. Bandung. Alfabeta

Tjiptono, F. (2008). Pemasaran Strategik. Yogyakarta: Andi Offset.

Widiana, M. E., Supit, H., \& Hartini, S. (2012). Penggunaan teknologi internet dalam sistem penjualan online untuk meningkatkan kepuasan dan pembelian berulang produk batik pada usaha kecil dan menengah di Jawa Timur. Jurnal manajemen dan kewirausahaan, 14(1), 72-82.

Winayu, N. (2013). Pengaruh Kepercayaan, Perceived Ease of Use dan Perceived Usefulness terhadap Minat Menggunakan E-Commerce Forum Jual Beli Kaskus. Skripsi UNY. Yogyakarta: Tidak diterbitkan.

Wahyuni \& Shabri, (2017). Pengaruh Sikap, Norma Subjektif, Percieved Behavioral Control dan Religiusitas Terhadap Niat Memiliki Rumah Berbasis Pembiayaan Syariah Di Kota Banda Aceh. Jurnal Administrasi Akuntansi: Program Pascasarjana Unsyiah, 6(2). 